\title{
Benchmarking passive transfer of immunity and growth in dairy calves
}

\author{
D. J. Atkinson, M. A. G. von Keyserlingk, and D. M. Weary ${ }^{1}$ \\ Animal Welfare Program, Faculty of Land and Food Systems, University of British Columbia, 2357 Main Mall, Vancouver, BC, V6T 1Z4 Canada
}

\begin{abstract}
Poor health and growth in young dairy calves can have lasting effects on their development and future production. This study benchmarked calf-rearing outcomes in a cohort of Canadian dairy farms, reported these findings back to producers and their veterinarians, and documented the results. A total of 18 Holstein dairy farms were recruited, all in British Columbia. Blood samples were collected from calves aged 1 to 7 d. We estimated serum total protein levels using digital refractometry, and failure of passive transfer (FPT) was defined as values below $5.2 \mathrm{~g} / \mathrm{dL}$. We estimated average daily gain (ADG) for preweaned heifers (1 to $70 \mathrm{~d}$ old) using heart-girth tape measurements, and analyzed early $(\leq 35 \mathrm{~d})$ and late $(>35 \mathrm{~d})$ growth separately. At first assessment, the average farm FPT rate was $16 \%$. Overall, ADG was $0.68 \mathrm{~kg} / \mathrm{d}$, with early and late growth rates of 0.51 and $0.90 \mathrm{~kg} / \mathrm{d}$, respectively. Following delivery of the benchmark reports, all participants volunteered to undergo a second assessment. The majority (83\%) made at least 1 change in their colostrum-management or milk-feeding practices, including increased colostrum at first feeding, reduced time to first colostrum, and increased initial and maximum daily milk allowances. The farms that made these changes experienced improved outcomes. On the 11 farms that made changes to improve colostrum feeding, the rate of FPT declined from $21 \pm 10 \%$ before benchmarking to $11 \pm 10 \%$ after making the changes. On the 10 farms that made changes to improve calf growth, ADG improved from $0.66 \pm 0.09 \mathrm{~kg} / \mathrm{d}$ before benchmarking to $0.72 \pm 0.08 \mathrm{~kg} / \mathrm{d}$ after making the management changes. Increases in ADG were greatest in the early milk-feeding period, averaging $0.13 \mathrm{~kg} / \mathrm{d}$ higher than pre-benchmarking values for calves $\leq 35 \mathrm{~d}$ of age. Benchmarking specific outcomes associated with calf rearing can motivate producer engagement in calf care, leading to improved outcomes for calves on farms that apply relevant management changes.
\end{abstract}

Received July 29, 2016.

Accepted January 4, 2017.

${ }^{1}$ Corresponding author: danweary@mail.ubc.ca
Key words: behavioral change, growth curve, passive immunity, morbidity

\section{INTRODUCTION}

Colostrum management is one of the most critical areas of calf care (Beam et al., 2009; Vogels et al., 2013). Calves rely on early consumption of colostrum to acquire immunoglobulins (McGrath et al., 2016). Colostrum quality depends on several factors, including the volume produced, the time of collection, the concentration of immunoglobulins, and bacteria levels (McGuirk and Collins, 2004; Godden, 2008). For successful passive transfer of immunoglobulins, of which 90\% are IgG (Larson et al., 1980), the calf must ingest the colostrum soon after birth (Weaver et al., 2000). Failure of passive transfer (FPT) is defined as a serum IgG concentration below $10 \mathrm{mg} / \mathrm{mL}$ (Faber et al., 2005; Beam et al., 2009). Negative outcomes associated with FPT include increased preweaning morbidity (Donovan et al., 1998) and mortality (Robison et al., 1988), increased duration of illness (Paré et al., 1993), increased contagiousness or pathogen shedding (Lopez et al., 1988), reduced growth (Dewell et al., 2006), reduced milk production in the first lactation, and increased culling rates (DeNise et al., 1989).

Although the importance of passive transfer has been studied extensively, dairy farms continue to struggle with FPT and its associated economic and welfare costs. For example, surveys have found FPT rates of 25 to $37 \%$ in Canada (Wallace et al., 2006; Trotz-Williams et al., 2008), 21\% in the United States (USDA, 2010), and $38 \%$ in Australia (Vogels et al., 2013). A survey of calf-management practices in Quebec, Canada, found that no farms evaluated colostrum quality or newborn passive transfer status (Vasseur et al., 2010). Survey data in the United States found that $15 \%$ of farms tested colostrum quality and only $6 \%$ routinely screened for FPT (USDA, 2016).

Another important measure for assessing calf-management success is ADG (Breen et al., 2012), but to our knowledge few dairy farmers track calf weights (Murray and Leslie, 2013) or set specific targets during the milk-feeding period. Moreover, thinking has changed 
considerably about milk-feeding practices: a developing literature indicates that providing more milk earlier in life can improve calf growth rates, reduce disease incidence, and facilitate greater solid feed intake when combined with an appropriate weaning strategy (Khan et al., 2011). Calves given free access to milk will often drink $10 \mathrm{~L} / \mathrm{d}$ or more (Jasper and Weary, 2002; de Passillé et al., 2011) and are capable of gaining $1 \mathrm{~kg} / \mathrm{d}$ (Sweeney et al., 2010; Eckert et al., 2015). However, recent US data show that $56 \%$ of farms continue to provide milk volumes of $5 \mathrm{~L} / \mathrm{d}$ or less, and only $22 \%$ feed $8 \mathrm{~L} / \mathrm{d}$ or more (USDA, 2016). Data from 2007 report ADG from birth to $69 \mathrm{~d}$ of $0.6 \mathrm{~kg} / \mathrm{d}$ (USDA, 2010).

Benchmarking is used in many fields, including health care and agriculture (Jarrar and Zairi, 2001; Bogetoft, 2012). Comparing one's own performance with others provides context to reflect on current practices and identify areas for improvement (Meade, 1994; Anand and Kodali, 2008). This approach may be especially useful for addressing complex multifactorial problems that require tailored solutions.

The aim of the current study was to assess the effects of benchmarking FPT and ADG in preweaned calves on dairy farms. We hypothesized that (1) farms would make management changes to improve these outcome measures, and (2) farms that made these changes would experience improved outcomes, but (3) farms that made no relevant changes would not experience improved outcomes.

\section{MATERIALS AND METHODS}

\section{Project Design}

Dairy farms were recruited from the client roster of the Greenbelt Veterinary Clinic (Chilliwack, BC, Canada). All farms were located in the lower Fraser Valley region of British Columbia, Canada. Inclusion criteria were a Holstein herd, and more than 100 milking cows. Exclusion criteria were current or recent (within the past year) inclusion in another University of British Columbia study, and routine use of a colostrum replacer. Of 19 farms approached, 18 agreed to participate. The average $[ \pm$ standard deviation $(\mathbf{S D})]$ size of the farms was $264 \pm 110$ lactating cows, with a range of 113 to 450 .

To facilitate logistics, participants were divided into 2 staggered cohorts, 1 consisting of 8 farms and the other consisting of 10 farms. Each cohort underwent an initial 7-wk period of on-farm data collection (starting in February and April 2014, respectively). Within 4 wk of the end of this initial data collection, we presented benchmark reports to the farms.
After receiving the report, the farms were offered the opportunity to participate in a second assessment period, regardless of whether they made changes. All 18 farms agreed to participate in this second period (identical to the first), starting $24 \pm 5 \mathrm{~d}$ (mean $\pm \mathrm{SD}$ ) after the initial benchmark report to consider and implement any changes.

Animal care aspects of this study were approved by the University of British Columbia Animal Care Committee (application A14-0245). Survey methods were approved by the University of British Columbia Behavioral Research Ethics Board (application H14-03196).

\section{Data Collection}

We conducted a survey of management practices in person during an initial farm visit; the first author interviewed the primary calf caretaker(s) on the farm. Survey items included general practices for preweaned calves, with a focus on colostrum and feeding protocols. At the beginning and end of the second round of data collection, the first author asked farmers to identify changes made over the course of the study.

Following recommended protocols for herd assessment of FPT of immunity (McGuirk and Collins, 2004), blood samples were collected weekly from all calves (heifers and bulls) aged 1 to $7 \mathrm{~d}$. On average $( \pm \mathrm{SD})$, $22 \pm 7$ calves were tested per farm during each round (minimum of 12); 380 calves were tested in round 1 , and 402 calves were tested in round 2 (Table 1 ).

Samples were collected by jugular venipuncture in red-top Vacutainer tubes (10.0-mL BD Vacutainer glass serum tube, silicone-coated; Becton Dickinson and Co., Franklin Lakes, NJ) and refrigerated for up to $24 \mathrm{~h}$. The serum was separated by centrifuge (Legend RT, Sorvall; ThermoFisher Scientific Inc., Waltham, MA) at $1,565 \times g$ at $5^{\circ} \mathrm{C}$ for $15 \mathrm{~min}$ and then stored at $-20^{\circ} \mathrm{C}$ until analysis. Measuring serum total protein (TP) via refractometry is a valid proxy measure for IgG and a practical method for assessing passive transfer of immunity in calves (Morrill et al., 2013; Deelen et al., 2014; Thornhill et al., 2015). Serum TP was measured 2 or 3 times (until 2 identical readings were recorded) with a temperature-compensating digital refractometer (AR200; Reichert Analytical Instruments, Reichert Inc., Depew, NY) to assess the state of passive transfer in each calf. Failure of passive transfer was defined as a serum TP score below $5.2 \mathrm{~g} / \mathrm{dL}$ (Tyler et al., 1996; Calloway et al., 2002).

Every second week, heart-girth tape measurements were taken from all preweaned calves $\leq 70 \mathrm{~d}$ of age, to a maximum of 25 animals per visit, with 3 to 4 visits per round. If a farm had more than 25 preweaned calves, 
we measured every second calf (in order of age). On average $( \pm \mathrm{SD}), 53 \pm 10$ measurements were taken per farm for each report; a total of 866 calves were taped in round 1 and 1,047 calves were taped in round 2 (Table 1 ). The same calf was never included in both rounds.

To obtain consistent measurement, calves were required to conform to a neutral standing posture, with all 4 legs straight and on even ground, head upright and forward, and the neck relaxed and not stretched or curved to the sides or back. A standard 150-cm measuring tape was passed under the chest behind the front legs and over the back, just behind the calves' withers. Measures were repeated 2 or 3 times until 2 identical readings were recorded.

To ensure reliability within and between the 2 assessors who performed on-farm taping, scoring sessions were carried out before the study began and between assessment rounds using 66 preweaned Holstein calves at the University of British Columbia's Dairy Education and Research Centre (Agassiz, BC, Canada). Each assessor alternated taping each calf twice and was blind to the other's score. These calves were also weighed using a scale (355 I.S.; GSE Avery Weight-Tronix, Fairmont, MN).

\section{Benchmarking}

Benchmark reports summarized each farm's passive transfer rates and ADG, together with the results from other farms (deidentified to maintain confidentiality). The herd veterinarian presented the report to the farm owner, manager, and primary calf caretaker. At least one of the current paper's authors also attended each meeting. After the content of the report had been explained, the farm owner and staff were encouraged to ask questions. The veterinarian, supported by the research staff, provided information in response to the questions and facilitated discussion about calf care.

\section{Statistical Analysis}

Farm-specific estimates for ADG were based on the slope of the linear regression predicting BW in relation to calf age (Bond et al., 2015). Average daily gain was estimated separately for younger (1-35 d) and older calves (36-70 d) because of differences in management and development, including differences in milk volumes offered and rumen anatomy and physiology (Borderas et al., 2009; de Passillé et al., 2011). Farm-level FPT was calculated as the total number of failures divided by the total number of calves assessed. Values were estimated separately for each farm before and after benchmarking. The effect of changes in management following benchmarking was analyzed using a paired $t$-test, comparing farm averages before and after benchmarking, and separately for farms that made relevant management changes and those that did not.

The repeat heart-girth measurements obtained by the 2 assessors during reliability testing sessions were analyzed for inter- and intra-observer agreement using Pearson correlation. The appropriateness of heart-girth estimations for this study was evaluated by comparing the mean estimated BW with scale weights using linear regression.

Table 1. Number of total protein and heart-girth samples collected from calves on participating farms and whether management changes intended to improve passive transfer and growth outcomes were implemented between assessment periods

\begin{tabular}{|c|c|c|c|c|c|c|c|}
\hline Farm & Cohort & \multicolumn{2}{|c|}{ Total protein samples (no.) } & \multicolumn{2}{|c|}{ Heart-girth samples (no.) } & $\begin{array}{l}\text { Colostrum } \\
\text { management changes }\end{array}$ & $\begin{array}{l}\text { Feed-management } \\
\text { changes }\end{array}$ \\
\hline 3 & 1 & 22 & 12 & 40 & 58 & No & No \\
\hline 4 & 1 & 24 & 32 & 41 & 53 & Yes & No \\
\hline 5 & 1 & 28 & 25 & 42 & 60 & Yes & Yes \\
\hline 8 & 1 & 25 & 28 & 51 & 53 & No & Yes \\
\hline 9 & 2 & 15 & 32 & 30 & 42 & Yes & No \\
\hline 10 & 2 & 17 & 18 & 52 & 48 & Yes & Yes \\
\hline 11 & 2 & 17 & 19 & 46 & 63 & Yes & Yes \\
\hline 12 & 2 & 19 & 13 & 48 & 55 & No & Yes \\
\hline 13 & 2 & 13 & 17 & 59 & 60 & Yes & No \\
\hline 14 & 2 & 13 & 15 & 42 & 58 & Yes & No \\
\hline
\end{tabular}


Table 2. Categorical calf-management practices reported by participating farms $(\mathrm{n}=18)$ at first assessment that were focused on colostrum-feeding practices and growth rates during the milk-feeding period $^{1}$

\begin{tabular}{llr}
\hline Management practice & Method & $\begin{array}{r}\text { Farms } \\
\text { (no.) }\end{array}$ \\
\hline Colostrum storage & None & 5 \\
& Refrigerated & 5 \\
Colostrum quality testing & Frozen & 8 \\
& Usually & 0 \\
& Rarely & 1 \\
Colostrum-feeding method & Never & 17 \\
Milk delivery frequency & Esophageal tube & 6 \\
& Bottle & 12 \\
Milk-feeding apparatus & Once per day/free choice & 1 \\
& Twice per day & 16 \\
Milk type given to calves & Three times per day & 1 \\
& Bucket & 10 \\
& Teat & 7 \\
& Multi-teat mob feeder & 2 \\
Milk volume ramp-up steps & Unpasteurized & 9 \\
& Pasteurized & 3 \\
Weaning process & Replacer & 5 \\
& None & 2 \\
& 1 orend & 2 \\
Calf housing & Gradual & 9 \\
& Abrupt & 7 \\
& Semi-abrupt & 11 \\
& Hutch & 6 \\
& Hutch and run & 1 \\
& Stall & 5 \\
& Pair/group pen & 7 \\
& & 6 \\
& & 5 \\
\hline
\end{tabular}

${ }^{1}$ Some farms used multiple methods; numbers do not total 18 for each variable.

\section{RESULTS}

\section{Before Benchmarking}

Management Practices. Participating farms reported a variety of calf-management practices relevant to the outcome measures being assessed (Table 2 and $3)$. Before the study, none of the farms regularly tested colostrum quality or monitored FPT. The maximum time to collect colostrum was $9.9 \pm 3.4 \mathrm{~h}$ (mean \pm SD). Eight farms maintained a frozen colostrum bank, 5 refrigerated colostrum, and 5 did not store colostrum. The maximum time to first colostrum feeding was 9.3 $\pm 3.9 \mathrm{~h}$, with 12 farms feeding primarily via bottle and teat, 5 via esophageal tube, and 1 varying methods depending on who was on staff at the time the calf was born. The minimum amount of colostrum fed at the first feeding was $2.6 \pm 0.8 \mathrm{~L}$.

Nine of the 18 farms milked twice per day, 7 milked 3 times per day, and 2 used automated free-choice milking stations. Sixteen farms fed milk twice per day, 1 farm fed 3 times per day, and 1 fed once per day. All farms offered milk by bottle and teat for the first 1 to $2 \mathrm{wk}$, but half of the farms transitioned to bucket feeding for the remainder of the milk-feeding period. Fresh waste milk was the primary liquid feed offered on half of the farms; pasteurized waste milk, milk replacer, and a blend of replacer and waste milk were fed on the remaining farms. Almost all farms offered increased volumes of milk to older and larger calves. Average initial and maximum daily milk offered increased from approximately 5 to $7.5 \mathrm{~L}$ respectively, with maximum milk volume reached at approximately 3 wk of age. Calves were weaned over an average of $7.6 \mathrm{~d}$ and were fully weaned from milk at an average age of $10 \mathrm{wk}$.

Passive Transfer of Immunity. At the first assessment, the mean $( \pm \mathrm{SD})$ serum TP was $5.8 \pm 0.2 \mathrm{~g} /$ $\mathrm{dL}$, with a range of 5.5 to $6.3 \mathrm{~g} / \mathrm{dL}$. The average FPT rate was $16 \pm 10 \%$, and ranged from 3 to $39 \%$ (Figure 1A) across the 18 farms.

Weight Gain. Pearson correlations and interclass correlation comparisons of heart-girth measurements for intra- and inter-reliability were at least 0.99 within and between all combinations of assessors. Regressing the mean estimated weights from the taping of 66 calves 1-70 d against true BW (as measured by the scale) yielded an $R^{2}$ of 0.97 .

Table 3. Quantitative calf-management practices reported by participating farms $(\mathrm{n}=18)$ at first assessment that were focused on colostrum-feeding practices and growth rates during the milk-feeding period

\begin{tabular}{llcl}
\hline Management variable & Measure & Mean \pm SD & Range \\
\hline Colostrum management & Maximum collection time (h) & $9.9 \pm 3.4$ & $1-14.5$ \\
& Maximum time to first feeding (h) & $9.3 \pm 3.9$ & $3-16$ \\
Feed management & Minimum amount of first feeding (L) & $2.6 \pm 0.8$ & $1.9-4.4$ \\
& Initial daily milk offered (L) & $5.1 \pm 2$ & $3.8-12.5$ \\
& Maximum daily milk offered (L) & $7.5 \pm 1.5$ & $5.7-12.5$ \\
& Age at maximum daily milk (d) & $23.6 \pm 16.8$ & $1-60$ \\
& Age ad libitum water offered (d) & $16.5 \pm 23.8$ & $1-90$ \\
& Age ad libitum grain offered (d) & $6.2 \pm 4.7$ & $1-17.5$ \\
& Age ad libitum forage offered (d) & $66.8 \pm 14.5$ & $42-90$ \\
Calf housing & Duration of weaning period (d) & $7.6 \pm 7.1$ & $0-21$ \\
& Age weaned by (d) & $72.8 \pm 11.1$ & $58-91$ \\
& Age when pair or group-housed (d) & $57.9 \pm 25.6$ & $7-90$ \\
\hline
\end{tabular}



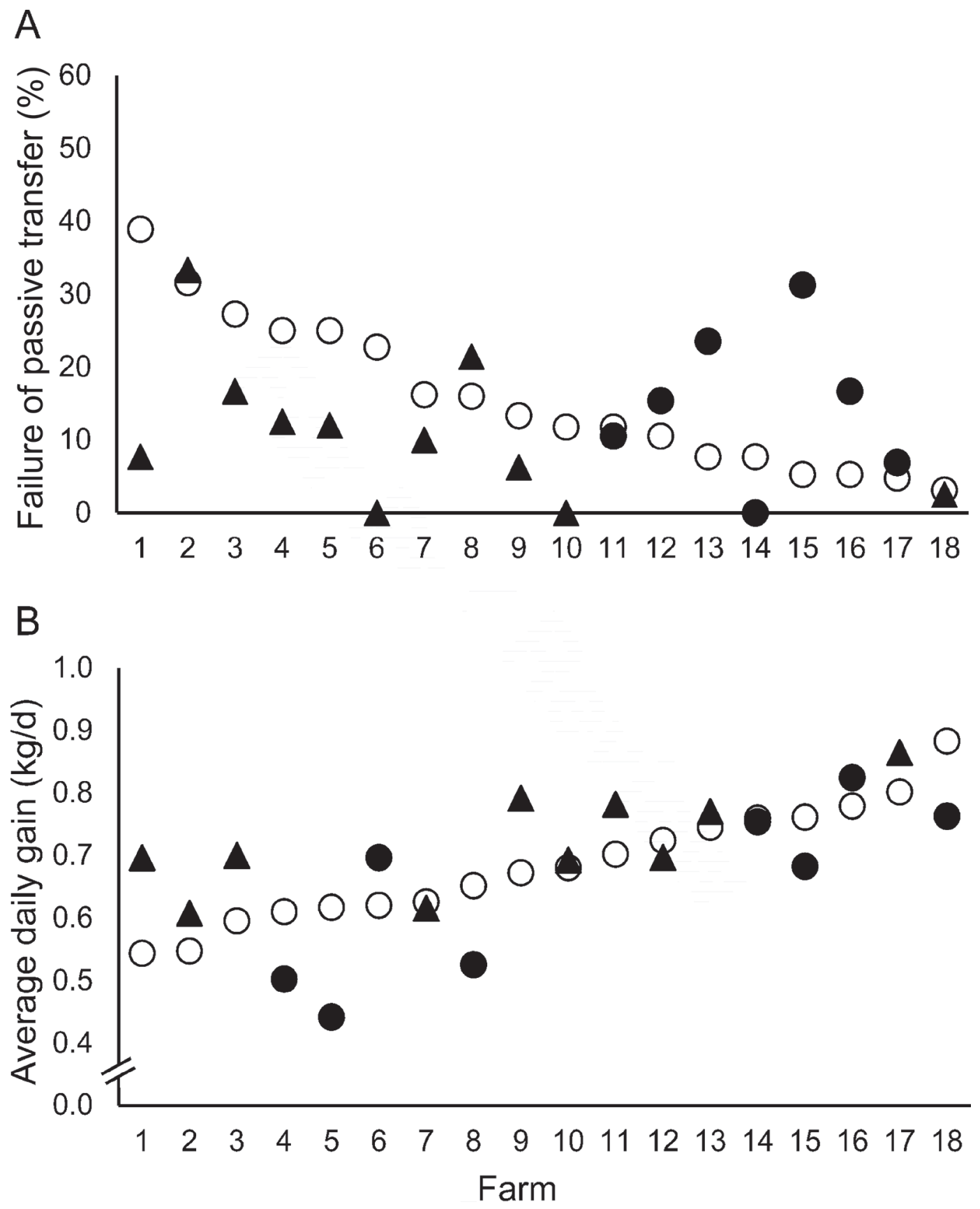

Figure 1. (A) Failure of passive transfer rates, and (B) ADG in preweaned Holstein calves on 18 farms before and after the benchmark intervention. Open circles show results before farms received the benchmarking reports and solid shapes show the same farms after the reportstriangles indicate farms that made relevant protocol changes after the report and circles indicate farms that made no changes.

The mean $( \pm \mathrm{SD})$ ADG at the first assessment was $0.68 \pm 0.09 \mathrm{~kg} / \mathrm{d}$ and ranged from 0.54 to $0.88 \mathrm{~kg} / \mathrm{d}$ across the 18 farms (Figure 1B). When calves were divided into early $(\leq 35 \mathrm{~d})$ or late $(>35 \mathrm{~d})$ preweaning groups, average gains were $0.51 \pm 0.12 \mathrm{~kg} / \mathrm{d}$ and 0.90 $\pm 0.19 \mathrm{~kg} / \mathrm{d}$, respectively.

\section{After Benchmarking}

Management Practices. Of the 18 participating farms, 15 elected to make at least 1 specific change related to either colostrum or milk-feeding practices. Of the 15 farms, 6 made changes to both management 
areas, 5 made colostrum-specific changes only, and 4 made milk-feeding management changes only (Table 1 ). One farm attempted a change but reverted to original operating procedures before the second assessment, and 2 farms made no changes.

The most common changes were to increase the amount of colostrum fed, the amount of milk initially fed, and the maximum amount of milk fed (Table 4). Considering only farms that made such a change, the average $( \pm \mathrm{SD})$ changes were as follows: colostrum feeding increased by $1.0 \pm 0.1 \mathrm{~L}$; initial milk offered increased by $2.1 \pm 1.7 \mathrm{~L} / \mathrm{d}$; and maximum milk offered increased by $2.2 \pm 1.5 \mathrm{~L} /$ d. Four farms also fed higher milk rations earlier in life; on these farms the maximum milk ration was offered $17.8 \pm 8.9 \mathrm{~d}$ earlier. Additional changes included altering standard colostrum-feeding procedures (quicker first feeding, additional feedings, recording time of feedings) and purchasing new equipment for testing (colostrometer or refractometer) and storing (freezer, refrigerator) colostrum.

Passive Transfer of Immunity. As predicted, farms that implemented specific changes to their colostrum management protocols experienced fewer cases of FPT than before these changes took place. Eleven farms made colostrum-related changes. On these farms, mean $( \pm \mathrm{SD}) \mathrm{FPT}$ was $21 \pm 10 \%$ before benchmarking versus $11 \pm 10 \%$ after making the management changes that followed the benchmark report [standard error of the difference (SED) 3.1\%, $P<0.01$; Figure $1 \mathrm{~A}]$. In contrast, FPT tended to increase on the 7 farms that did not change their colostrum management; before benchmarking, mean FPT was $8 \pm 3 \%$, compared with $15 \pm 10 \%$ on the same farms after benchmarking (SED $4.7 \%, P<0.1)$.

Weight Gain. Ten farms reported specific protocol changes intended to improve calf weight gain after the first assessment. On these 10 farms, mean $( \pm \mathrm{SD}) \mathrm{ADG}$ was $0.66 \pm 0.09 \mathrm{~kg} / \mathrm{d}$ before benchmarking and $0.72 \pm$ $0.08 \mathrm{~kg} / \mathrm{d}$ after making the management changes that followed the benchmark report (SED $0.02 \mathrm{~kg} / \mathrm{d}, P<$ 0.05 ; Figure 1B). Considering only the younger calves $(\leq 35 \mathrm{~d})$, the mean $( \pm \mathrm{SD})$ ADG on these 10 farms increased from $0.48 \pm 0.15 \mathrm{~kg} / \mathrm{d}$ to $0.61 \pm 0.11 \mathrm{~kg} / \mathrm{d}$ after benchmarking (SED $0.05 \mathrm{~kg} / \mathrm{d} ; P<0.05$ ). For calves older than $35 \mathrm{~d}$, mean ADG on these 10 farms did not differ after benchmarking, at $0.84 \pm 0.16 \mathrm{~kg} / \mathrm{d}$ before and $0.81 \pm 0.13 \mathrm{~kg} / \mathrm{d}$ after $($ SED $0.07 \mathrm{~kg} / \mathrm{d} ; P>0.1$ ).

For the 8 farms that made no specific management changes, we observed no difference between assessments. On these 8 farms, mean $( \pm \mathrm{SD})$ ADG was 0.71 $\pm 0.10 \mathrm{~kg} / \mathrm{d}$ before benchmarking and $0.65 \pm 0.14 \mathrm{~kg} / \mathrm{d}$ after the benchmark report (SED $0.03 \mathrm{~kg} / \mathrm{d}, P>0.1$ ). Considering only the younger calves $(\leq 35 \mathrm{~d})$, mean ADG on these 8 farms did not differ, at $0.53 \pm 0.09$ $\mathrm{kg} / \mathrm{d}$ before and $0.53 \pm 0.09 \mathrm{~kg} / \mathrm{d}$ after benchmarking (SED $0.03 \mathrm{~kg} / \mathrm{d} ; P>0.1$ ). For calves older than $35 \mathrm{~d}$ on these 8 farms, we observed high variability and no change, with average $( \pm \mathrm{SD}) \mathrm{ADG}$ of $0.97 \pm 0.20 \mathrm{~kg} / \mathrm{d}$

Table 4. Calf-management changes reported by participating farms $(\mathrm{n}=18)$ at first assessment that were focused on colostrum-feeding practices and growth rates during the milk-feeding period

\begin{tabular}{llc}
\hline Management variable & Description of changes & Farms (no.) \\
\hline Colostrum management & Increase amount of first feeding & 8 \\
& Provide additional feedings & 3 \\
& Undertake quality testing & 3 \\
& Record time of initial feeding & 2 \\
& Reduce time before initial feeding & 2 \\
Acquire storage equipment ${ }^{2}$ & 2 \\
& Increase esophageal tube use & 2 \\
Train additional staff to feed newborn calves & 1 \\
& Install calving pen milk line for first milking & 1 \\
No changes & 7 \\
& Increase initial milk volume & 7 \\
& Increase maximum milk volume & 7 \\
& Reduce days until maximum milk volume & 4 \\
& Introduce early stepdown in milk volume & 4 \\
& Provide water sooner & 2 \\
& Provide additional daily feeding & 1 \\
& Provide hay & 1 \\
& Provide additional teats for group-housed calves & 1 \\
\hline
\end{tabular}

${ }^{1}$ Via colostrometer, refractometer, or veterinary clinic.

${ }^{2}$ Refrigerator or freezer. 
before and $0.83 \pm 0.16 \mathrm{~kg} / \mathrm{d}$ after benchmarking (SED $0.09 \mathrm{~kg} / \mathrm{d} ; P>0.1)$.

\section{DISCUSSION}

\section{Producer Engagement and Changed Practices}

Little research to date has systematically assessed the effects of participating in a benchmarking program relevant to dairy management. Our group's earlier work, benchmarking lameness and skin injuries in adult cows, was based on a single report (von Keyserlingk et al., 2012; Barrientos et al., 2013; Chapinal et al., 2013). Our only data to assess the effectiveness of this approach in changing practices was from a convenience sample, using farms that invited us to return for a second assessment approximately 1 yr after the first report. This sample of producers appeared to be motivated to change practices, and showed improvements in lameness and hock injuries (Chapinal et al., 2014). In contrast, the current study followed all farms before and after receiving a benchmark report.

We did not consider it feasible to maintain a control group that did not receive a benchmarking report because of the high likelihood of cross-talk between farms in the community (Main et al., 2012). Instead, each farm acted as its own control; outcome measures were compared before and after the intervention. This means that comparisons were necessarily confounded by time. However, it is unlikely that the differences we found for farms that changed their practices were due to any general temporal effect, because the farms in the same cohort that made no relevant changes were tested at exactly the same times and showed no evidence of improvement. We concluded that benchmarking motivated some farms to adopt new practices, and that these farms experienced improved outcomes.

This study was not designed to determine which aspects of the benchmarking process were effective. It is likely that our presence on the farm and our measurements of these factors affected producer interest and management. Further experimental work would be necessary to disentangle the various aspects of our process to determine which were most effective in motivating changed practices.

Nevertheless, our results showed a high level of producer interest in data from their farm on FPT and $\mathrm{ADG}$, as demonstrated by the high participation rate in this study (18 of 19 farms invited), and the $100 \%$ retention rate from round 1 to round 2 of assessment. By design, the participating farms were not asked to perform any specific changes. However, most farms (15 of 18) chose to make specific changes in consultation with their veterinarian.

\section{Passive Transfer of Immunity}

Recommended best practices to prevent FPT include feeding a minimum of $4 \mathrm{~L}$ of high-quality colostrum within $6 \mathrm{~h}$ of calving (Godden, 2008). Increasing the volume of colostrum fed was the most common change producers made; fewer farms introduced changes aimed at improving the quality and timing of the first colostrum feeding, likely because these changes required more effort and planning. Of the 16 farms that milked cows in a milking parlor, 11 collected colostrum exclusively during regular milking times, imposing a delay in feeding without access to a colostrum bank. Counterintuitively, the longest delays to feeding of first colostrum were on farms that milked 3 times daily, because on these farms the evening milking staff were not typically trained to care for newborn calves.

The current study was not designed to test the effects of specific interventions, and our sample size was inadequate to evaluate the types of changes that were most effective. However, our results indicate that farms that made some change were able to improve their performance, and that farms that did not make relevant management changes showed no improvement. It was also the case that farms with relatively high rates of FPT were most likely to adopt changes. That farms with the lowest performance before benchmarking were more likely to change practice is not surprising, but it also introduces a bias, because by chance alone farms at the low end of the distribution might be expected to improve and vice versa, reflecting a simple regression toward the mean (Barnett et al., 2005). Indeed, 7 of the 8 farms with the lowest FPT during the first assessment chose to make no changes to their colostrum management, and these farms showed somewhat poorer performance in the second round of testing, perhaps because they were now focusing on other management issues. The present study was designed to allow farmers to adopt the changes that they saw fit, but future studies could avoid this issue by experimentally assigning farms to specific interventions.

Past surveys that used a similar threshold for FPT found rates of 21 to 38\% (USDA, 2010; Vogels et al., 2013), far above current standards that recommend a threshold of $10 \%$ FPT to be considered of minimum concern (McGuirk, 2010). The average FPT for farms in this study were relatively low, averaging $16 \%$ across all 18 farms at the first assessment and $13 \%$ at the second assessment. This value declined to just $11 \%$ for 
the 11 farms that made changes in their colostrumfeeding practices after benchmarking, suggesting that motivated and informed producers can reach FPT rates that approach current recommendations.

\section{Weight Gain}

We estimated calf weights from tape measurements. This method is practical for this type of on-farm study, where scales are either unavailable or impractical. Previous work has shown that body taping can provide reliable estimates of actual BW in young calves (Heinrichs et al., 1992). Some authors have expressed concerns about the accuracy of tape measures for calves under 3 mo of age (Dingwell et al., 2006; Heinrichs et al., 2007), but the results of our validation work suggest that this method is sufficiently accurate for use in these younger animals (see also Bond et al., 2015). In preliminary work, we found that inconsistencies in calf posture added some error to the estimates, so we recommend training in the use of weight tapes with specific attention to consistency in calf posture and tape positioning.

The most common management changes by farms that wanted to improve preweaning gains were to feed more milk earlier in life. Traditional restricted milkfeeding programs have typically provided approximately $4 \mathrm{~L} / \mathrm{d}$, compared with more recent accelerated programs that advocate $8 \mathrm{~L} / \mathrm{d}$ or more in the preweaning period (Khan et al., 2011), especially in the first few weeks of life when calves are unable to digest solid feeds (Baldwin et al., 2004). At first assessment, almost every participating farm in this study used a step-up milk-feeding protocol, increasing volume incrementally with age, as observed by Vasseur et al. (2010). Following the benchmark report, some producers focused on increasing milk volume in the first few weeks of life, which may explain why daily gains improved substantially for calves $\leq 35 \mathrm{~d}$. Some participants introduced a step down in milk volume at 35 to $45 \mathrm{~d}$ to encourage solid feed intake before weaning and minimize weaning stress (Khan et al., 2007). This study did not follow calves through weaning, but increased gains in accelerated programs before weaning are not guaranteed to carry through to breeding age, particularly when early or abrupt weaning methods are used (Sweeney et al., 2010; Eckert et al., 2015). We recommend that future studies follow calves through weaning to better identify the effects of weaning practices on calf growth and health.

As with the FPT results, farms that made feed-management changes tended to show greater improvements in ADG than farms that did not. In this case, however, initial ranking and the decision to make changes were not closely linked, suggesting that the improvements in ADG were related to the changes made rather than a regression to the mean.

\section{CONCLUSIONS}

Producers were motivated to participate in a benchmarking program that gave them their own data and relevant comparators for FPT and ADG in milk-fed calves. Participation in the program also appeared to motivate management changes intended to improve performance. Farms that applied relevant management changes experienced improved performance in both FPT and ADG.

\section{ACKNOWLEDGMENTS}

We are grateful to students at the University of British Columbia Dairy Centre, especially Christine Sumner, Samantha Jung, and Christine Cummins for their help in all aspects of this study, and to the veterinarians of the Greenbelt Veterinary Services, Phil Chris, Dick Clegg, John Dick, Dan McDermid, Jason Ricka, and Josh Waddington, for their collaboration and encouragement - this study would not have been possible without their help. We also thank the participants from the 6 pilot farms and the 18 experimental farms that allowed us to come onto their farms and whose participation made this study possible. This research was funded via the Natural Sciences and Engineering Research Council's Industrial Research Chair program, with industry contributions from the Dairy Farmers of Canada (Ottawa, ON, Canada), British Columbia Dairy Association (Burnaby, BC, Canada), Westgen Endowment Fund (Milner, BC, Canada), Intervet Canada Corporation (Kirkland, QC, Canada), Novus International Inc. (Oakville, ON, Canada), Zoetis (Kirkland, QC, Canada), BC Cattle Industry Development Fund (Kamloops, BC, Canada), Alberta Milk (Edmonton, AB, Canada), Valacta (St. Anne-deBellevue, QC, Canada), and CanWest DHI (Guelph, ON, Canada).

\section{REFERENCES}

Anand, G., and R. Kodali. 2008. Benchmarking the benchmarking models. Benchmarking Int. J. 15:257-291. https://doi. org $/ 10.1108 / 14635770810876593$.

Baldwin, R. L., K. R. McLeod, J. L. Klotz, and R. N. Heitmann. 2004. Rumen development, intestinal growth and hepatic metabolism in the pre- and postweaning ruminant. J. Dairy Sci. 87:E55-E65. https://doi.org/10.3168/jds.S0022-0302(04)70061-2.

Barnett, A. G., J. C. van der Pols, and A. J. Dobson. 2005. Regression to the mean: What it is and how to deal with it. Int. J. Epidemiol. 34:215-220. https://doi.org/10.1093/ije/dyh299. 
Barrientos, A., N. Chapinal, D. M. Weary, E. Galo, and M. A. G. von Keyserlingk. 2013. Herd-level risk factors for hock injuries in freestall-housed dairy cows in the northeastern United States and California. J. Dairy Sci. 96:3758-3765.

Beam, A. L., J. E. Lombard, C. A. Kopral, L. P. Garber, A. L. Winter, J. A. Hicks, and J. L. Schlater. 2009. Prevalence of failure of passive transfer of immunity in newborn heifer calves and associated management practices on US dairy operations. J. Dairy Sci. 92:3973-3980. https://doi.org/10.3168/jds.2009-2225.

Bogetoft, P. 2012. Performance Benchmarking: Measuring and Managing Performance. Springer Science and Business Media, New York, NY.

Bond, G. B., M. G. von Keyserlingk, N. Chapinal, E. A. Pajor, and D. M. Weary. 2015. Among farm variation in heifer BW gains. Animal 9:1884-1887. https://doi.org/10.1017/S175173111500097X.

Borderas, T. F., A. M. B. de Passillé, and J. Rushen. 2009. Feeding behavior of calves fed small or large amounts of milk. J. Dairy Sci. 92:2843-2852. https://doi.org/10.3168/jds.2008-1886.

Breen, J., P. Down, M. Kerby, A. Bradley, and M. Green. 2012. Restoring the dairy herd: Rearing youngstock and replacing cows. Pages 35-72 in Dairy Herd Health. M. R. Green, ed. CABI Publishing, Boston, MA.

Calloway, C. D., J. W. Tyler, R. K. Tessman, D. Hostetler, and J. Holle. 2002. Comparison of refractometers and test endpoints in the measurement of serum protein concentration to assess passive transfer status in calves. J. Am. Vet. Med. Assoc. 221:1605-1608. https://doi.org/10.2460/javma.2002.221.1605.

Chapinal, N., A. Barrientos, M. A. G. von Keyserlingk, E. Galo, and D. M. Weary. 2013. Herd-level risk factors for lameness in freestall farms in northeastern United States and California. J. Dairy Sci. 96:318-328.

Chapinal, N., D. M. Weary, L. Collings, and M. A. G. von Keyserlingk. 2014. Lameness and hock injuries improve on farms participating in an assessment program. Vet. J. 202:646-648. https://doi. org/10.1016/j.tvj1.2014.09.018.

de Passillé, A. M., T. F. Borderas, and J. Rushen. 2011. Weaning age of calves fed a high milk allowance by automated feeders: Effects on feed, water, and energy intake, behavioral signs of hunger, and weight gains. J. Dairy Sci. 94:1401-1408. https://doi.org/10.3168/ jds.2010-3441.

Deelen, S. M., T. L. Ollivett, D. M. Haines, and K. E. Leslie. 2014. Evaluation of a Brix refractometer to estimate serum immunoglobulin G concentration in neonatal dairy calves. J. Dairy Sci. 97:3838-3844. https://doi.org/10.3168/jds.2014-7939.

DeNise, S. K., J. D. Robison, G. H. Stott, and D. V. Armstrong. 1989. Effects of passive immunity on subsequent production in dairy heifers. J. Dairy Sci. 72:552-554. https://doi.org/10.3168/ jds.S0022-0302(89)79140-2.

Dewell, R. D., L. L. Hungerford, J. E. Keen, W. W. Laegreid, D. D. Griffin, G. P. Rupp, and D. M. Grotelueschen. 2006. Association of neonatal serum immunoglobulin G1 concentration with health and performance in beef calves. J. Am. Vet. Med. Assoc. 228:914-921. https://doi.org/10.2460/javma.228.6.914.

Dingwell, R. T., M. M. Wallace, C. J. McLaren, C. F. Leslie, and K. E. Leslie. 2006. An evaluation of two indirect methods of estimating body weight in Holstein calves and heifers. J. Dairy Sci. 89:39923998. https://doi.org/10.3168/jds.S0022-0302(06)72442-0.

Donovan, G. A., I. R. Dohoo, D. M. Montgomery, and F. L. Bennett. 1998. Associations between passive immunity and morbidity and mortality in dairy heifers in Florida, USA. Prev. Vet. Med. 34:3146. https://doi.org/10.1016/S0167-5877(97)00060-3.

Eckert, E., H. E. Brown, K. E. Leslie, T. J. DeVries, and M. A. Steele. 2015. Weaning age affects growth, feed intake, gastrointestinal development, and behavior in Holstein calves fed an elevated plane of nutrition during the preweaning stage. J. Dairy Sci. 98:6315-6326. https://doi.org/10.3168/jds.2014-9062.

Faber, S. N., N. E. Faber, T. C. Mccyauley, and R. L. Ax. 2005. Case study: Effects of colostrum ingestion on lactational performance. Prof. Anim. Sci. 21:420-425. https://doi.org/10.15232/S10807446(15)31240-7.
Godden, S. 2008. Colostrum management for dairy calves. Vet. Clin. North Am. Food Anim. Pract. 24:19-39. https://doi.org/10.1016/j. cvfa.2007.10.005.

Heinrichs, A. J., H. N. Erb, G. W. Rogers, J. B. Cooper, and C. M. Jones. 2007. Variability in Holstein heifer heart-girth measurements and comparison of prediction equations for live weight. Prev. Vet. Med. 78:333-338. https://doi.org/10.1016/j.prevetmed.2006.11.002.

Heinrichs, A. J., G. W. Rogers, and J. B. Cooper. 1992. Predicting body weight and wither height in Holstein heifers using body measurements. J. Dairy Sci. 75:3576-3581. https://doi.org/10.3168/ jds.S0022-0302(92)78134-X.

Jarrar, Y. F., and M. Zairi. 2001. Future trends in benchmarking for competitive advantage: A global survey. Total Qual. Manage. 12:906-912. https://doi.org/10.1080/09544120120096034.

Jasper, J., and D. M. Weary. 2002. Effects of ad libitum milk intake on dairy calves. J. Dairy Sci. 85:3054-3058. https://doi.org/10.3168/ jds.S0022-0302(02)74391-9.

Khan, M. A., H. J. Lee, W. S. Lee, H. S. Kim, S. B. Kim, K. S. Ki, J. K. Ha, H. G. Lee, and Y. J. Choi. 2007. Pre- and postweaning performance of Holstein female calves fed milk through step-down and conventional methods. J. Dairy Sci. 90:876-885. https://doi. org/10.3168/jds.S0022-0302(07)71571-0.

Khan, M. A., D. M. Weary, and M. A. G. von Keyserlingk. 2011. Invited review: Effects of milk ration on solid feed intake, weaning, and performance in dairy heifers. J. Dairy Sci. 94:1071-1081. https://doi.org/10.3168/jds.2010-3733.

Larson, B. L., H. L. Heary, and J. E. Devery. 1980. Immunoglobulin production and transport by the mammary gland. J. Dairy Sci. 63:665-671. https://doi.org/10.3168/jds.S0022-0302(80)82988-2.

Lopez, J. W., S. D. Allen, J. Mitchell, and M. Quinn. 1988. Rotavirus and Cryptosporidium shedding in dairy calf feces and its relationship to colostrum immune transfer. J. Dairy Sci. 71:1288-1294. https://doi.org/10.3168/jds.S0022-0302(88)79685-X.

Main, D. C., K. A. Leach, Z. E. Barker, A. K. Sedgwick, C. M. Maggs, N. J. Bell, and H. R. Whay. 2012. Evaluating an intervention to reduce lameness in dairy cattle. J. Dairy Sci. 95:2946-2954. https:// doi.org/10.3168/jds.2011-4678.

McGrath, B. A., P. F. Fox, P. L. H. McSweeney, and A. L. Kelly. 2016. Composition and properties of bovine colostrum: A review. Dairy Sci. Technol. 96:133-158. https://doi.org/10.1007/s13594015-0258-x.

McGuirk, S. M. 2010. Herd-Based Problem Solving: Failure of Passive Transfer. University of Wisconsin, Madison.

McGuirk, S. M., and M. Collins. 2004. Managing the production, storage, and delivery of colostrum. Vet. Clin. North Am. Food Anim. Pract. 20:593-603. https://doi.org/10.1016/j.cvfa.2004.06.005.

Meade, P. H. 1994. A Guide to Benchmarking. University of Otago, Dunedin, New Zealand.

Morrill, K. M., J. Polo, A. Lago, J. Campbell, J. Quigley, and H. Tyler. 2013. Estimate of serum immunoglobulin G concentration using refractometry with or without caprylic acid fractionation. J. Dairy Sci. 96:4535-4541. https://doi.org/10.3168/jds.2012-5843.

Murray, C. F., and K. E. Leslie. 2013. Newborn calf vitality: Risk factors, characteristics, assessment, resulting outcomes and strategies for improvement. Vet. J. 198:322-328. https://doi.org/10.1016/j. tvj1.2013.06.007.

Paré, J., M. C. Thurmond, I. A. Gardner, and J. P. Picanso. 1993. Effect of birthweight, total protein, serum IgG and packed cell volume on risk of neonatal diarrhea in calves on two California dairies. Can. J. Vet. Res. 57:241-246.

Robison, J. D., G. H. Stott, and S. K. DeNise. 1988. Effects of passive immunity on growth and survival in the dairy heifer. J. Dairy Sci. 71:1283-1287. https://doi.org/10.3168/jds.S0022-0302(88)796848.

Sweeney, B. C., J. Rushen, D. M. Weary, and A. M. de Passillé. 2010. Duration of weaning, starter intake, and weight gain of dairy calves fed large amounts of milk. J. Dairy Sci. 93:148-152. https://doi. org/10.3168/jds.2009-2427.

Thornhill, J. B., G. L. Krebs, and C. E. Petzel. 2015. Evaluation of the Brix refractometer as an on-farm tool for the detection of pas- 
sive transfer of immunity in dairy calves. Aust. Vet. J. 93:26-30. https://doi.org/10.1111/avj.12287.

Trotz-Williams, L. A., K. E. Leslie, and A. S. Peregrine. 2008. Passive immunity in Ontario dairy calves and investigation of its association with calf management practices. J. Dairy Sci. 91:3840-3849. https://doi.org/10.3168/jds.2007-0898.

Tyler, J. W., D. D. Hancock, S. M. Parish, D. E. Rea, T. E. Besser, S. G. Sanders, and L. K. Wilson. 1996. Evaluation of 3 assays for failure of passive transfer in calves. J. Vet. Intern. Med. 10:304-307. https://doi.org/10.1111/j.1939-1676.1996.tb02067.x.

USDA. 2010. Dairy 2007: Heifer calf health and management practices on U.S. operations. USDA, Fort Collins, CO.

USDA. 2016. Dairy 2014: Dairy cattle management practices in the United States, 2014. USDA, Fort Collins, CO.

Vasseur, E., F. Borderas, R. I. Cue, D. Lefebvre, D. Pellerin, J. Rushen, K. M. Wade, and A. M. de Passillé. 2010. A survey of dairy calf management practices in Canada that affect animal welfare. J. Dairy Sci. 93:1307-1315. https://doi.org/10.3168/jds.2009-2429.
Vogels, Z., G. Chuck, and J. Morton. 2013. Failure of transfer of passive immunity and agammaglobulinaemia in calves in south-west Victorian dairy herds: Prevalence and risk factors. Aust. Vet. J. 91:150-158. https://doi.org/10.1111/avj.12025.

von Keyserlingk, M. A. G., A. Barrientos, K. Ito, E. Galo, and D. M. Weary. 2012. Benchmarking cow comfort on North American freestall dairies: Lameness, leg injuries, lying time, facility design, and management for high-producing Holstein dairy cows. J. Dairy Sci. 95:7399-7408. https://doi.org/10.3168/jds.2012-5807.

Wallace, M. M., B. D. Jarvie, N. R. Perkins, and K. E. Leslie. 2006. A comparison of serum harvesting methods and type of refractometer for determining total solids to estimate failure of passive transfer in calves. Can. Vet. J. 47:573-575.

Weaver, D. M., J. W. Tyler, D. C. VanMetre, D. E. Hostetler, and G. M. Barrington. 2000. Passive transfer of colostral immunoglobulins in calves. J. Vet. Intern. Med. 14:569-577. https://doi. org/10.1111/j.1939-1676.2000.tb02278.x. 